Prepared for the U.S. Department of Energy under Contract DE-AC05-76RL01830

Topical Report

SECA

Investigation of Performance of SCN-1 Pure Glass as Sealant Used in SOFC

W.N Liu

$X$. Sun

E.V. Stephens

M.A. Khaleel

March 2010

Pacific Northwest

NATIONAL LABORATORY

Proudly Operated by Battelle Since 1965 


\title{
DISCLAIMER
}

This report was prepared as an account of work sponsored by an agency of the United States Government. Neither the United States Government nor any agency thereof, nor Battelle Memorial Institute, nor any of their employees, makes any warranty, express or implied, or assumes any legal liability or responsibility for the accuracy, completeness, or usefulness of any information, apparatus, product, or process disclosed, or represents that its use would not infringe privately owned rights. Reference herein to any specific commercial product, process, or service by trade name, trademark, manufacturer, or otherwise does not necessarily constitute or imply its endorsement, recommendation, or favoring by the United States Government or any agency thereof, or Battelle Memorial Institute. The views and opinions of authors expressed herein do not necessarily state or reflect those of the United States Government or any agency thereof.

\author{
PACIFIC NORTHWEST NATIONAL LABORATORY \\ operated by \\ BATTELLE \\ for the \\ UNITED STATES DEPARTMENT OF ENERGY \\ under Contract DE-AC05-76RL01830
}

Printed in the United States of America
Available to DOE and DOE contractors from the Office of Scientific and Technical Information,
P.O. Box 62, Oak Ridge, TN 37831-0062;
ph: (865) 576-8401
fax: $(865) 576-5728$
email: reports@adonis.osti.gov

\footnotetext{
Available to the public from the National Technical Information Service, U.S. Department of Commerce, 5285 Port Royal Rd., Springfield, VA 22161 ph: (800) 553-6847 fax: $(703) 605-6900$ email: orders@ntis.fedworld.gov online ordering: http://www.ntis.gov/ordering.htm
}

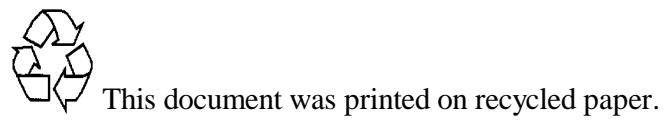




\section{Investigation of Performance of SCN-1 Pure Glass Used in SOFC}

W. N. Liu

X. Sun

E.V. Stephens

M. A. Khaleel

March 2010

Prepared for the SECA Core Technology Program

National Energy Technology Laboratory, Pittsburgh, Pennsylvania

under Contract DE-AC05-76RL01830

Pacific Northwest National Laboratory

Richland, Washington 99352 


\section{Executive Summary}

As its nam e im plies, a self -healing glass $\mathrm{s}$ eal has the po tential of re storing its $\mathrm{m}$ echanical properties upon being reheated to SOFC stack operating tem perature, even $\mathrm{w}$ hen it has experienced som e cooling induced damage/cracking at roo $\mathrm{m}$ temperature. Such a self-healing feature is desirable for achievi ng high seal reliability during th ermal cycling. On the other hand, self-healing glass is a lso characterized by its low mechanical stiffness and high creep rate at the typical operating temperature of SOFCs. Therefore, from a design perspective, it is important to know the lo ng term geom etric stab ility and ther mal m echanical behav iors of th e s elf-healing glass under the stack op erating cond itions. Thes e predictive capabilities will guide the design and optimization of a reliable sealing system that potentially utilizes self-healing glass as well as other ceramic seal components in achieving the ultimate goal of SOFC.

In this report, we focus on predicting the effects of various generic seal design parameters on the stresses in the seal. For this purpose, we take the test cell us ed in the leakage tests for compliant glass seals conducted at PNNL as our initial modeling geom etry. The effect of the ceram ic stopper on the geom etry stability of the self-heali ng glass sealants is studied first. Then we explore the effect of va rious in terfaces such as stopper and gla ss, stopper and P EN, as well stopper and IC plate, on the geom etry stability and reliability of glass during the operating and cooling processes. 


\section{Acronyms}

CTE coefficient of thermal expansion

FE f inite element

NETL National Energy Technology Laboratory

SECA Solid-State Energy Conversion Alliance

SEM scanning electron microscopy

SOFC solid-oxide fuel cell 


\section{Acknowledgements}

Pacific Northwest National Laboratory is operated for the U.S. Department of Energy by Battelle under Contract DE-AC05-76RL01830. The work summarized in this report was funded as part of the Solid-State Energy Conversion Alliance Core Technology Program by the U.S. Department of Energy's National Energy Technology Laboratory. We would like to acknowledge the technical direction from Travis Shultz and Briggs White. Technical discussions with Drs. Matt Chou and Jeff Stevenson are also gratefully acknowledged. 


\section{Contents}

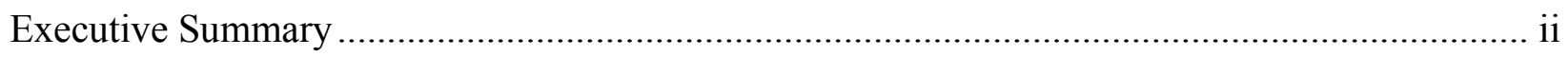

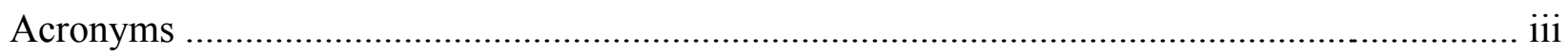

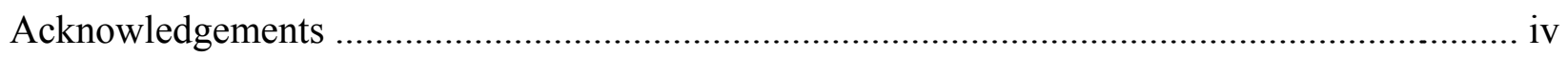

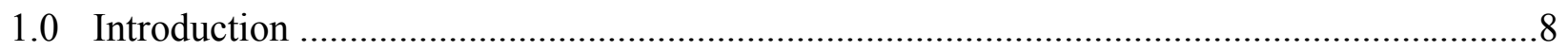

2.0 Technical Approach and Model Description...........................................................

3.0 Results and Discussions on Parametric Study .............................................................15

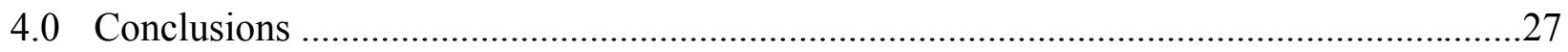

5.0 References 


\section{Figures}

Figure 1 Setup of leakage test (provided by Matt Chou) .................................................

Figure 2 Geometry of PEN, ceramic stopper and seal in the test cell ....................................9

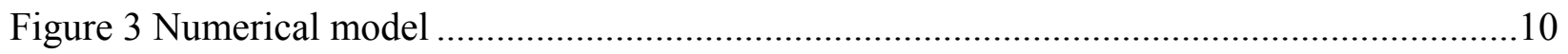

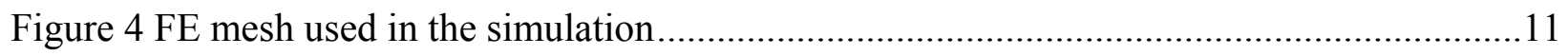

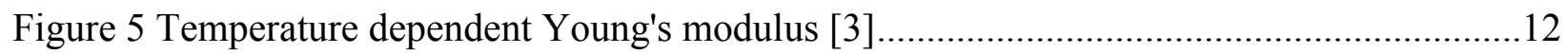

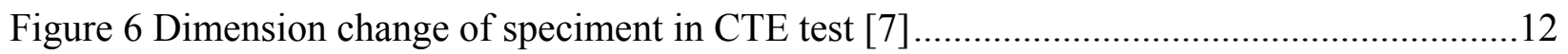

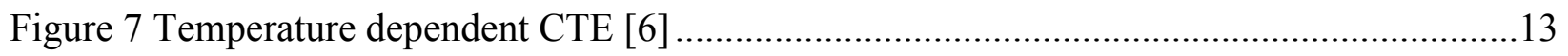

Figure 8 Setup of viscosity measurement with TMA. (a) before viscosity measurement; (b) after viscosity measurement.................................................................................... 14

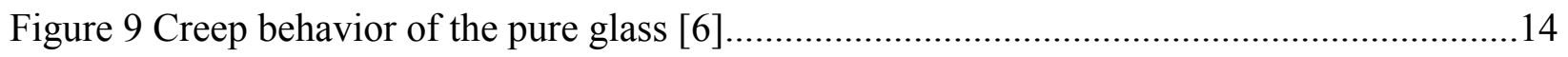

Figure 10 Schematic of model of setup without ceramic stoppers ........................................16

Figure 11 Deformed configurations (a) after applying top pressure; (b) creep in 2s .................16

Figure 12 Deformation history of the inner side if the glass ................................................ 17

Figure 13 Deformed glass with distribution of equivalent creep strain after creep. (a) 36s of creep without stopper; (b) 1000 s of creep with ceramic stopper ...........................................18

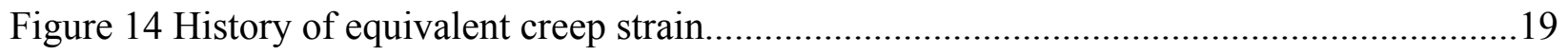

Figure 15 Maximum principal stress contour of glass seal at the different time:weak interface

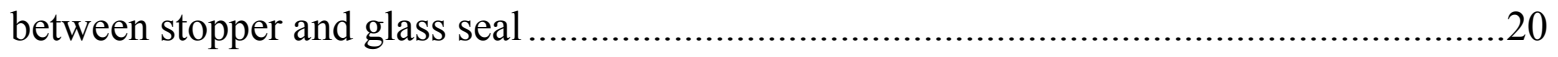

Figure 16 Shear stress S12 contour of glass seal at the different time: weak interface between

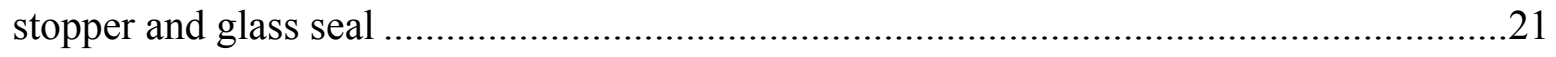

Figure 17 Maximum pricipal stress contour of glass seal at the different: strong interface of

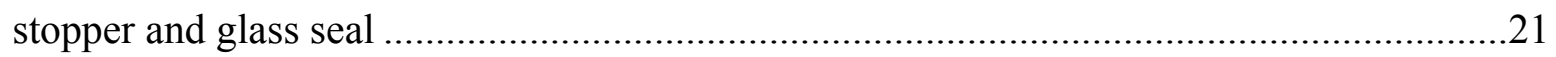

Figure 18 Shear stress S12 contour of glass seal at the different time: strong interface of stopper

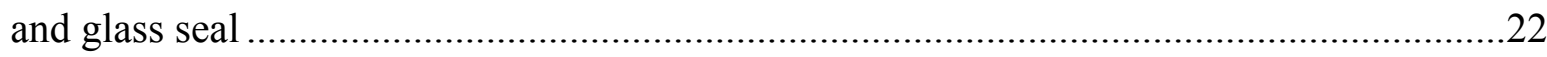

Figure 19 Shear stress distribution during the shutdown process with strong and weal interfaces

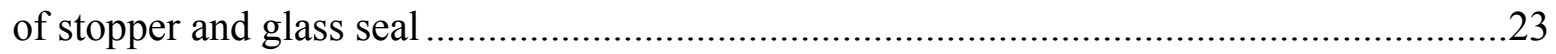

Figure 20 Normal stress distribution during the shutdown process with strong and weak interface

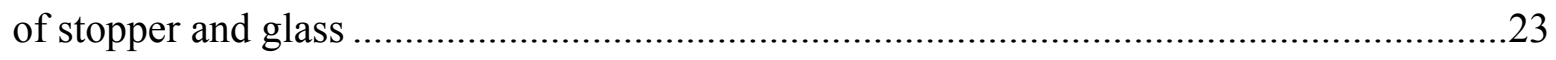


Figure 21 No sliding interface of stopper with PEN and IC: interfacial shear stress of glass (a)

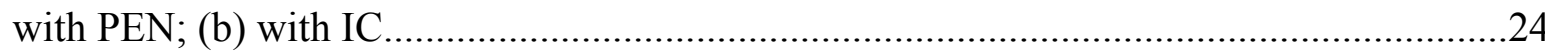

Figure 22 No sliding interface of stopper with PEN and IC: interfacial normal stress of glass with (a) PEN; (b) IC

Figure 23 Sliding interface of stopper with PEN: interfacial shear stress of glass with (a) PEN; (b) IC .25

Figure 24 Sliding interface of stopper with PEN: interfacial normal stress of glass with (a) PEN; (b) IC 26

Figure 25 Sliding interfaces of stopper with PEN and IC: interfacial shear stress of glass with (a) PEN; (b) IC. .26

Figure 26 Sliding interfaces of stopper with PEN and IC: interfacial normal stress of glass with (a) PEN; (b) IC 


\subsection{Introduction}

Seals are the $\mathrm{m}$ ost critical com ponents in co mmercializing the planar SOFC technology. They must adequately prevent the leakage of air and fuel, effectively isolate the fuel from the oxidant, and insulate the cell f rom short cir cuit. Glass joining is widely acc epted in SOFC as a sea ling approach since it provides a cost effective and relatively simple method for bonding ceramic and metal parts. However, the sof tening point of the glass com ponent typically limits the maximum operating temperature to which the joint may be exposed.

As its nam e im plies, a self -healing glass $\mathrm{s}$ eal has the po tential of re storing its $\mathrm{m}$ echanical properties upon being reheated to stack operating temperature [1,2], even when it has experienced som e cooling induced dam age/crack at room tem perature. Such a self-healing feature is desirable for achievi ng high seal reliability during th ermal cycling. On the other hand, self-healing glass is a lso characterized by its low mechanical stiffness and high creep rate a the typical operating temperature of SOFCs. Therefore, from a design perspective, it is important to know the lo ng term geom etric stab ility and ther mal m echanical behav iors of th e s elf-healing glass under the stack op erating cond itions. Thes e predictive capabilities will guide the design and optimization of a reliable sealing system that potentially utilizes self-healing glass as well as other ceramic seal components in achieving the ultimate goal of SOFC.

In this report, we focus on predicting the effects of various generic seal design parameters on the stresses in the seal. For this purpose, we take the test cell us ed in the leakage tests for compliant glass seals conducted at PNNL as our initial modeling geom etry. The effect of the ceram ic stopper on the geom etry stability of the self-heali ng glass sealants is studied first. Then we examine the influence of interfacial strength at various interfaces, i.e., stopper/glass, stopper/PEN, as well as stopper/IC pl ate, on the geometry stability and reliability of glass during the operating and cooling processes. 


\subsection{Technical Approach and Model Description}

Figure 1 and Figure 2 show the test setup and the associated seal geo metry of the test cell, respectively.

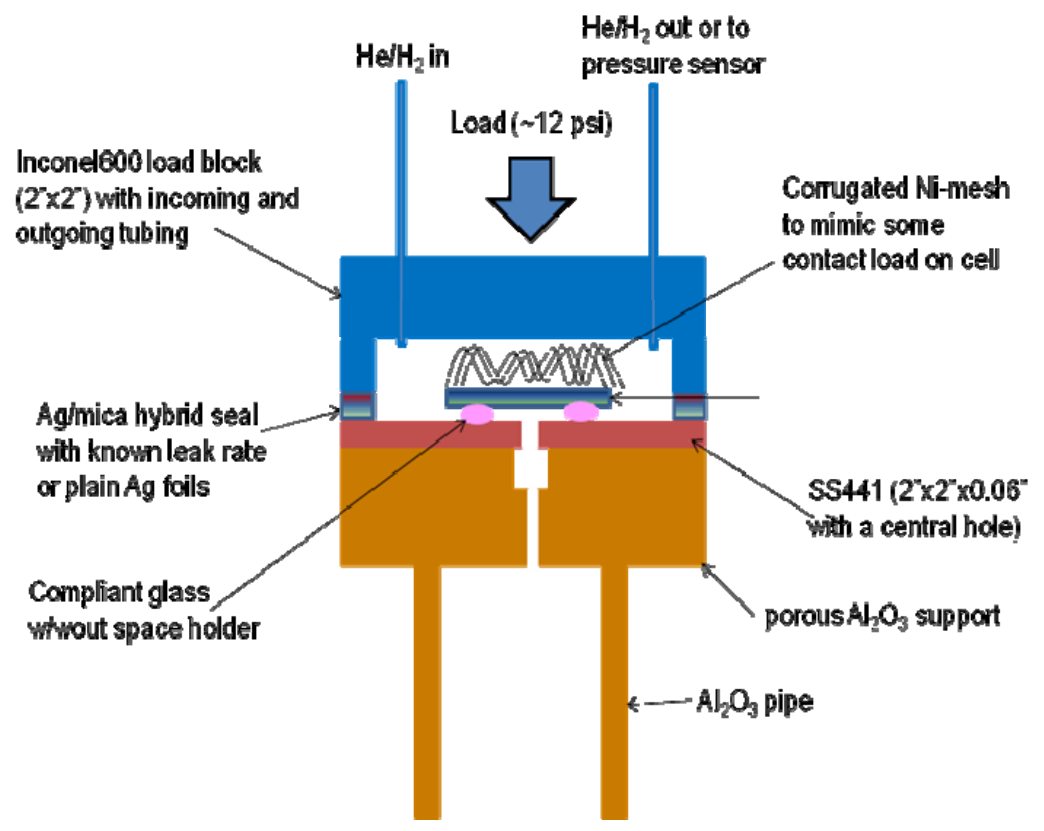

Figure 1 Setup of leakage test (provided by Matt Chou)
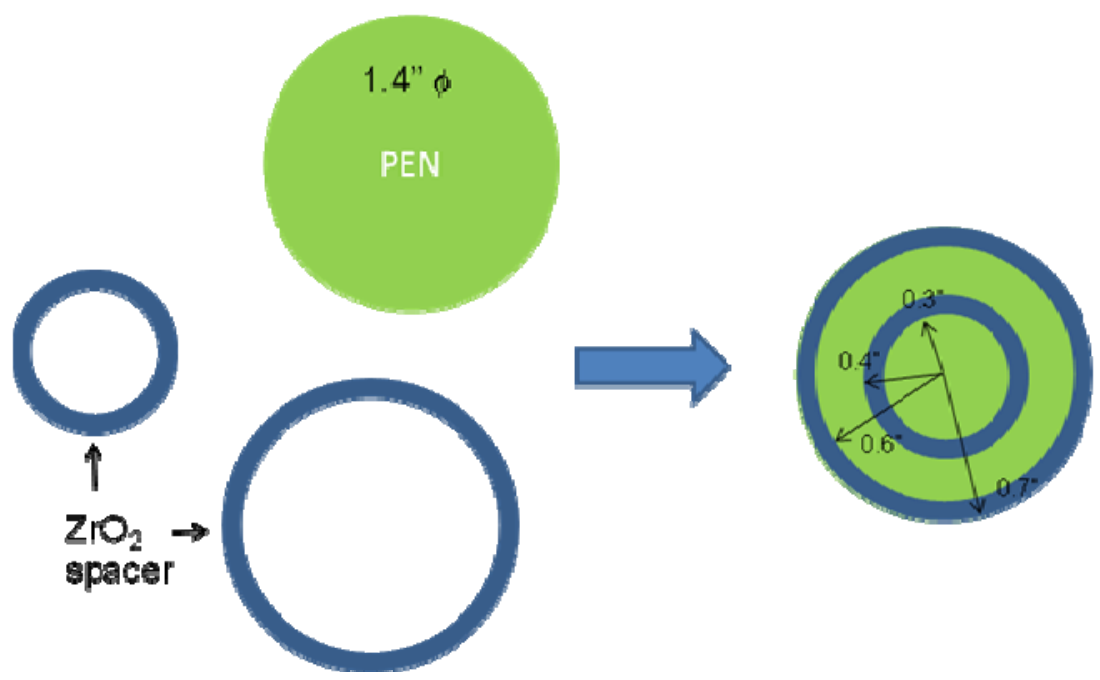

Figure 2 Geometry of PEN, ceramic stopper and seal in the test cell 
To simulate the glass behavior in the test, only the core part of the setup in Figure 1 is taken into account, which includes PEN, stopper/glass, and IC plate. Figure 3 shows the com putational cross-section of the tes $t$ cell. Utilizing the sy mmetrical nature of the test cell ge ometry, a 2 dimensional axisymm etric m odel is used in th is study. The test cell includes PEN (anode, electrolyte, and cathode), ceramic stoppers, glass seal, and SS 441 interconnect.

The sim ulation was perform ed usi ng the comm ercial finite elem ent (FE) software packag e MARC. Figure 4 shows the FE $m$ esh used in th e simulation with details around the seal, PEN and IC interface area. T wo types of sealing syst ems are considered: $100 \%$ glass seals, and glas s seals with ceramic stopper rings at both inner and outer radius of the glass seal, see Figure 3 .

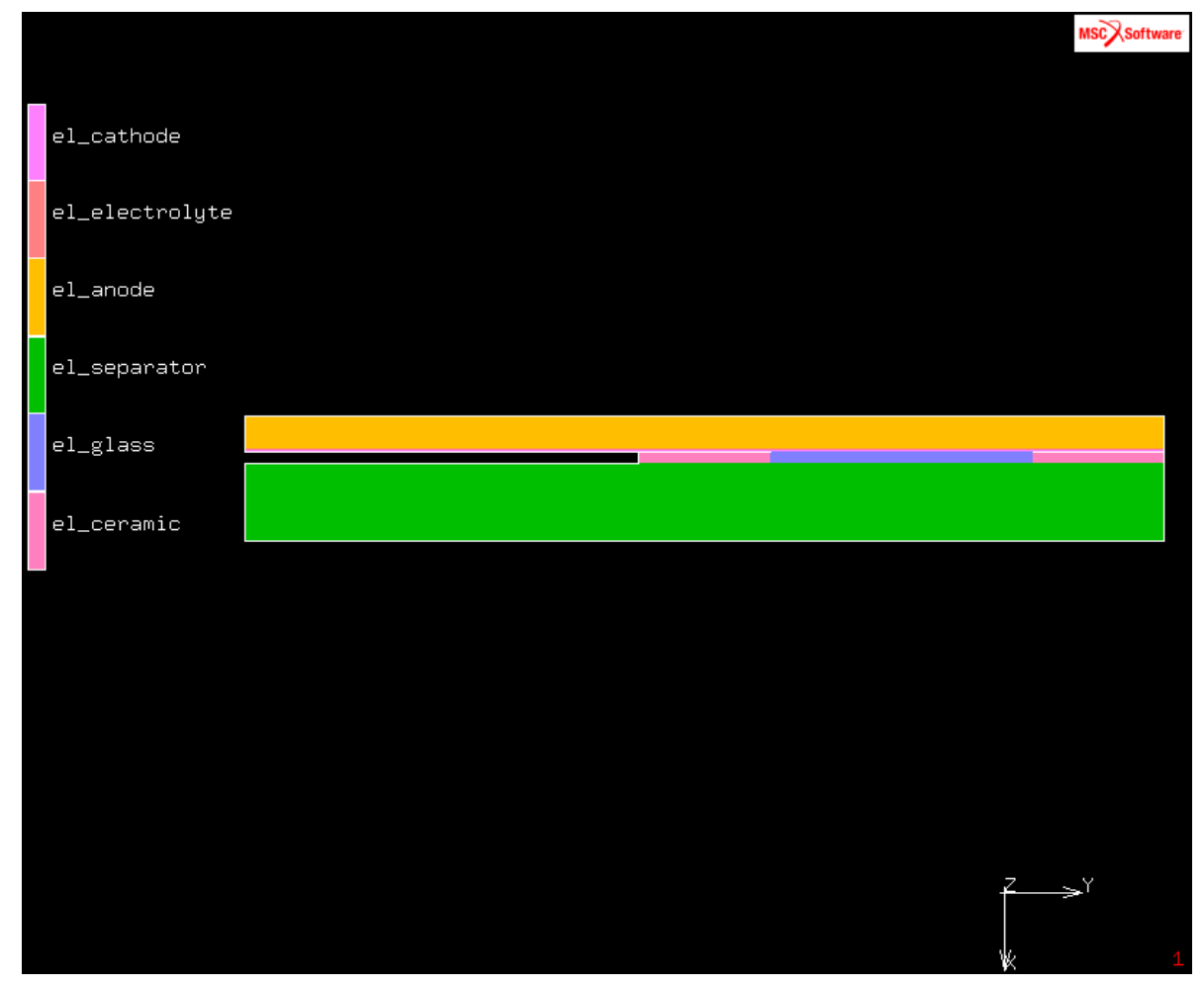

Figure 3 Numerical model 


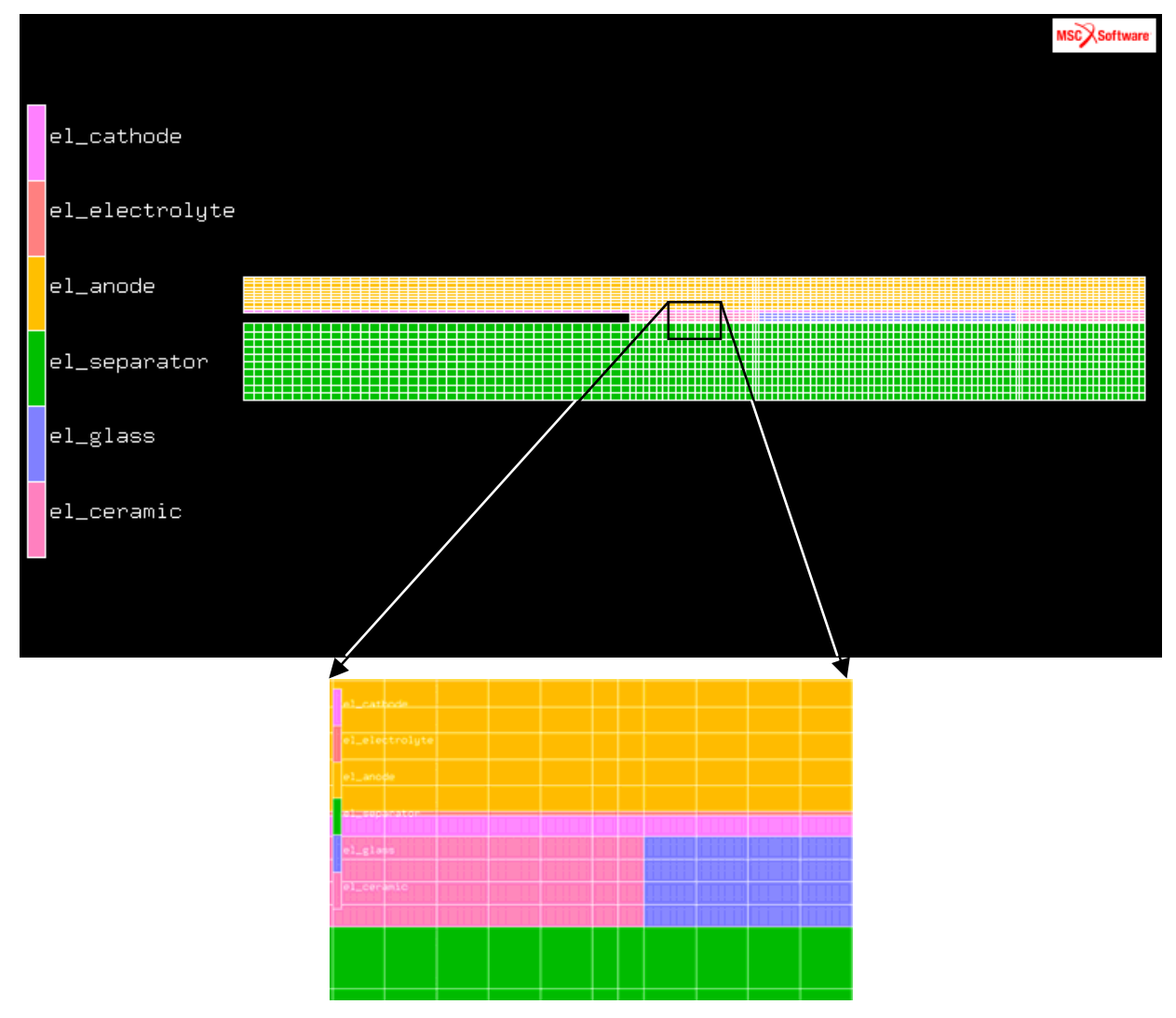

Figure 4 FE mesh used in the simulation

Currently, SCN-1 is used as the pure glass seal in the test cell modeling. Its thermal and mechanical properties are temperature dependent. Figure 5 depicts the temperature dependent Young's modulus, partially measured experimentally by ORNL [3]. It may be seen that the measurement was only conducted up to the glass transition temperature, i.e., $\mathrm{Tg}$ of this glass. This is because the testing method is no longer valid when the temperature exceeds Tg. In this analysis, the high temperature modulus is extrapolated in a manner consistent with typical glass behavior $[4,5]$.

The glass transition temperature $\mathrm{Tg}$ of $\mathrm{SCN}-1$ is about $500^{\circ} \mathrm{C}$, which is substantially lower than the typical operating temperature of SOFC $\left(\sim 800^{\circ} \mathrm{C}\right)$. The ORNL measured CTE for SCN-1 [7] only goes to about $600^{\circ} \mathrm{C}$, see Figure 6, so temperature dependent CTE data from the literature [6] was used in the current simulation (see Figure 7) for temperatures greater than $600{ }^{\circ} \mathrm{C}$. 


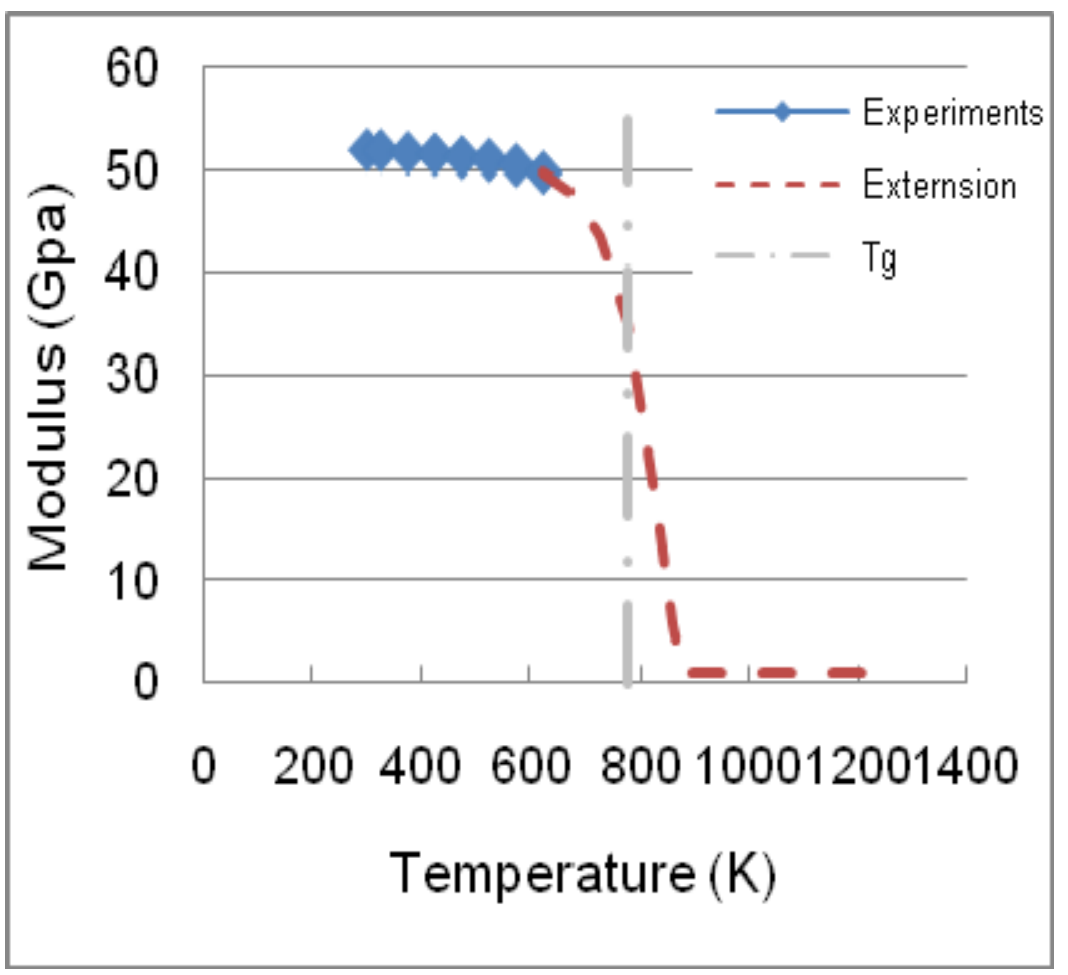

Figure 5 Temperature dependent Young's modulus [3]

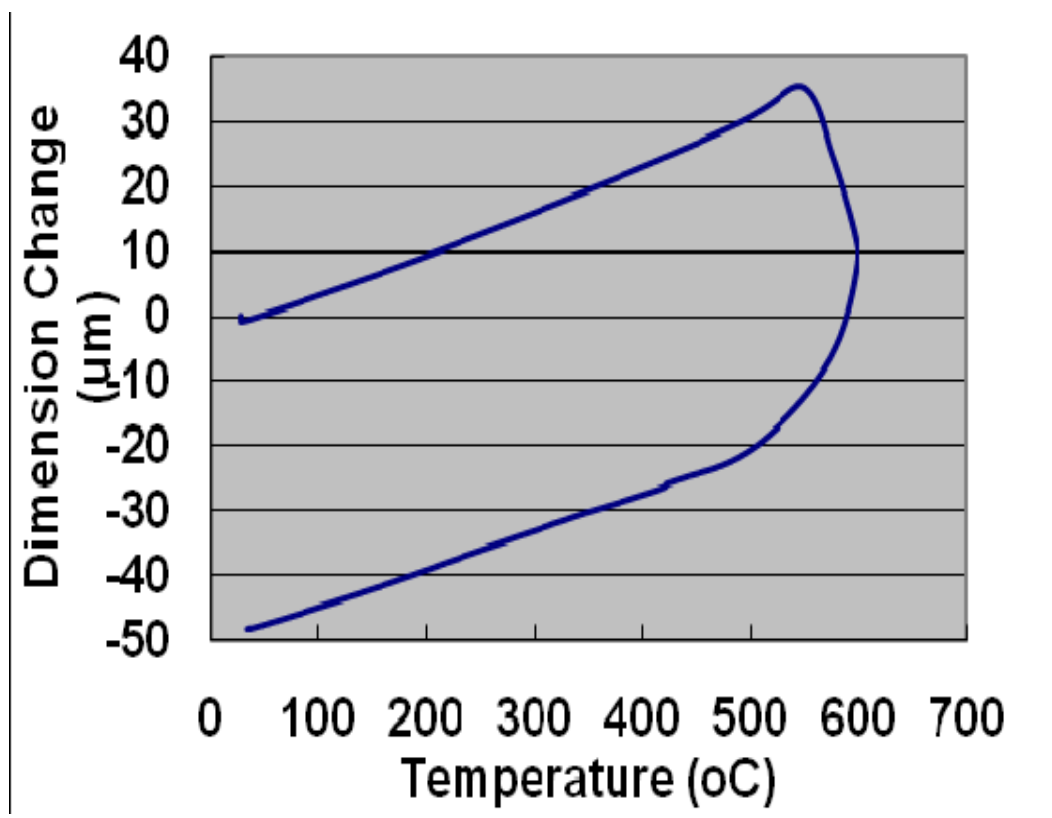

Figure 6 Dimension change of specimen in CTE test [7] 


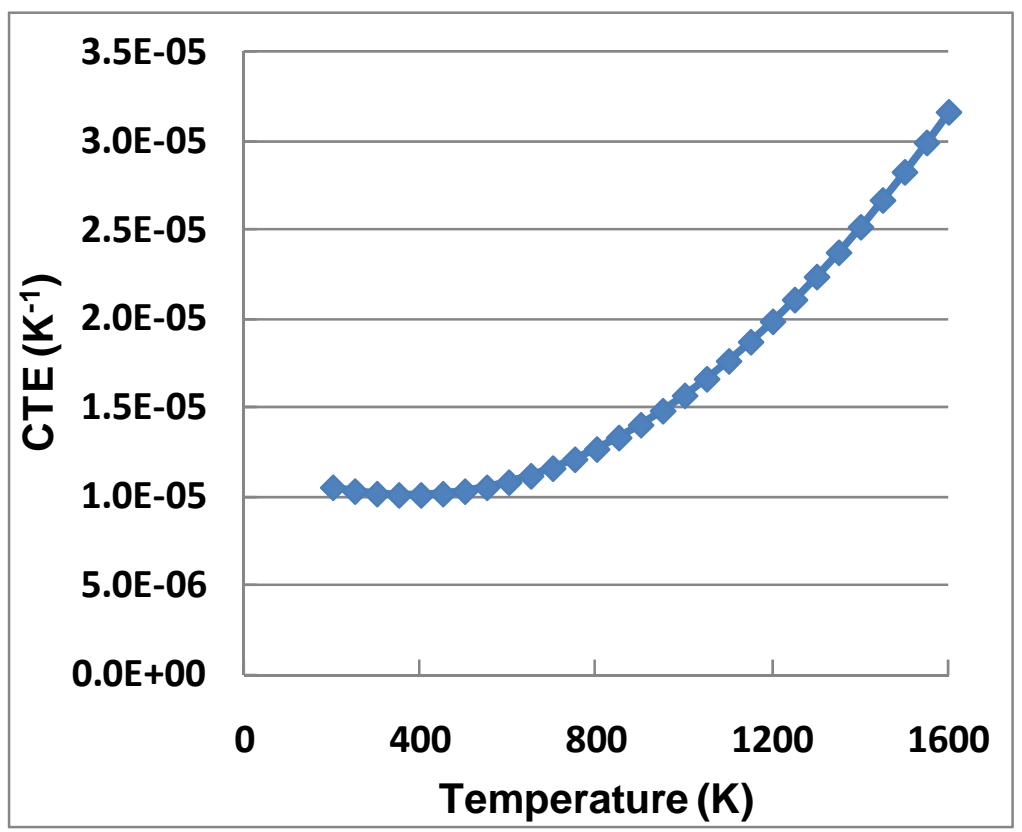

Figure 7 Temperature dependent CTE [6]

At the typical operating tem perature of SOFC, c reep behavior of the pure glass is unavoidable. Its creep behavior at high tem perature was measured at ORNL using the setup shown in Figure 8. The $\mathrm{m}$ easurements were performed isot hermally at tem peratures between $600{ }^{\circ} \mathrm{C}$ and $850{ }^{\circ} \mathrm{C}$. Three different loads were used in the viscosity measurement. A constant heating rate of $5^{\circ} \mathrm{C} / \mathrm{min}$ was applied under a constant load [8].

Viscous behavior of the pure glass can be evaluated by the linear creep law in equation (1.1) [8]:

$$
\dot{\varepsilon}=\frac{1}{\eta} \sigma(0.1)
$$

where

$$
\eta=\eta_{0} \exp \left(\frac{Q_{V}}{R T}\right)(0.2)
$$

$R$ is the universal gas constant with a value of $8.314 \mathrm{~J} / \mathrm{K} / \mathrm{mol}$. Based on the measurement results, the parameters for SNC-1 self-healing glass can be determined as $\eta_{0}=1.397 \times 10^{-9} \mathrm{~Pa} \cdot \mathrm{s}$, 
$Q_{v}=283.32 \mathrm{~kJ} / \mathrm{mol}[6]$. The viscous parameter $\eta$ of the self-healing glass is plotted as a function of temperature in Figure 9.

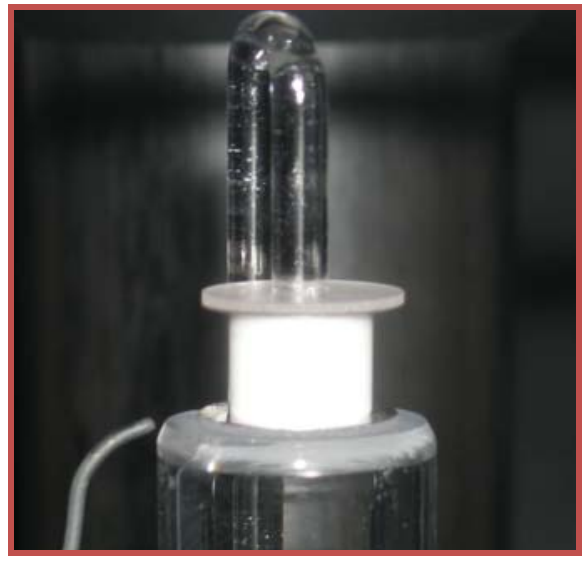

(a)

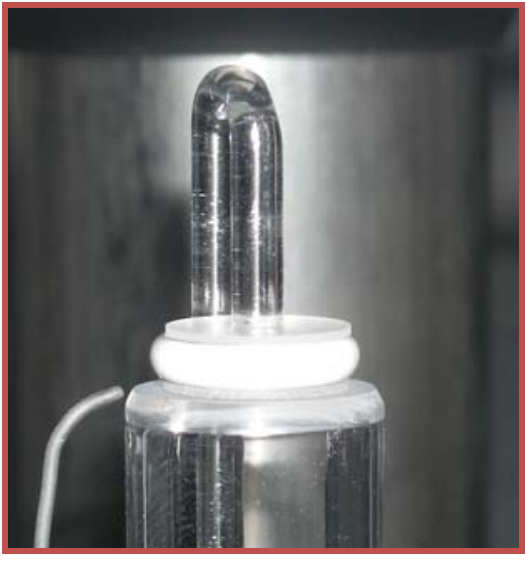

(b)

Figure 8 Setup of viscosity measurement with TMA. (a) before viscosity measurement; (b) after viscosity measurement

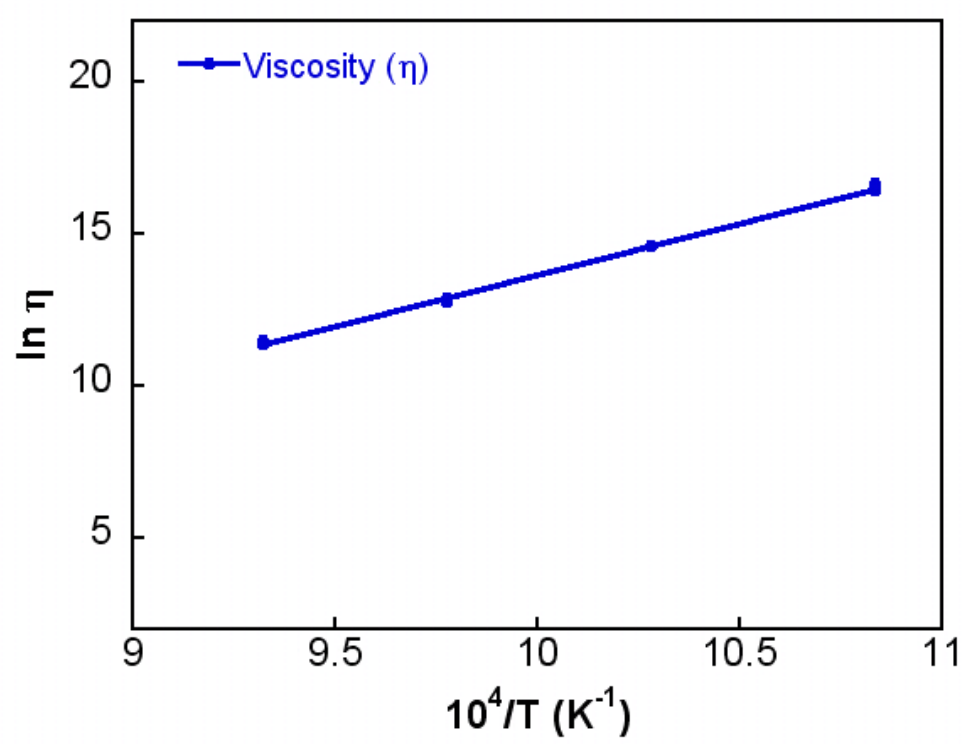

Figure 9 Creep behavior of the pure glass [6] 
The initial s tress-free te mperature is assum ed to be the stack assem bly tem perature of $850{ }^{\circ} \mathrm{C}$. The operating temperature is $800^{\circ} \mathrm{C}$. The test cell is given the initial stress-free temperature, then dropped to the operating tem perature in a quasi-static analysis step. The CTE $\mathrm{m}$ ismatch among various components will lead to various degrees of thermal stresses in different components due to the temperature drop. However, at the constant stack operating temperature, the glass seal will creep under the thermal stress, resulting in stress relaxation and redistribution. Upon shutdown of the test cell and cooling down to $t$ he room temperature of $25{ }^{\circ} \mathrm{C}$, new therm al stresses will b e created due to the CTE m ismatch. We will present the glass seal stress and the inte rfacial stress distributions at different stages of the therm al profile described above to com pare the effects of these different sealing systems.

\subsection{Results and Discussions on Parametric Study}

To explore the perform ance of the self-healing glass in SOFC stacks, different design and interface co nditions were consid ered. At first, the behavio $r$ of the glas $s$ was stud ied with and without ceramic stoppers. Then, the effect of vi scosity of the glass at high tem perature on the stress in the glass was s tudied using creep anal ysis. Subsequently, the in terfacial conditions in the ceramic stopper/glass, stopper/P EN, as well st opper/IC plate interfaces were investigated at two extreme conditions: fully bonded and sliding. For the stopper and glass interface, two cases were considered, one with a gap of $0.0635 \mathrm{~mm}$ between the stopper and glass seal, and one with no gap between them.

\section{Geometry Stability of the Glass Seal}

In the first case, pure SCN-1 glas s seal was applied without the cer amic stoppers at its inner and outer radius, see Figure 10. A constant pressu re of $0.08 \mathrm{MPa}$ was applied on the to $\mathrm{p}$ surface of PEN. The glass was allowed to flo $w$ freely alo ng the interfaces with PE N and IC plate. The deformed configurations immediately after the pressure application and after 2 seconds of creep deformation are illustrated in Figure 11, respectively. Immediately after the application of the top

pressure, the glas s s till keeps its o riginal g eometry. However, the g lass is predicted to flo $\mathrm{w}$ 
quickly with time in creep analysis. The final thickness of the glass is almost invisible. Figure 12 shows the history of defor mation of left side, i.e., inner radius, of the glass. $T$ he in-plane deformation increases almost linearly, and the thickness of the glass decreases in the same linear manner. That $m$ eans that the glass will quickly flow out between the PEN and IC plate if no physical containment is established at the PEN and IC.

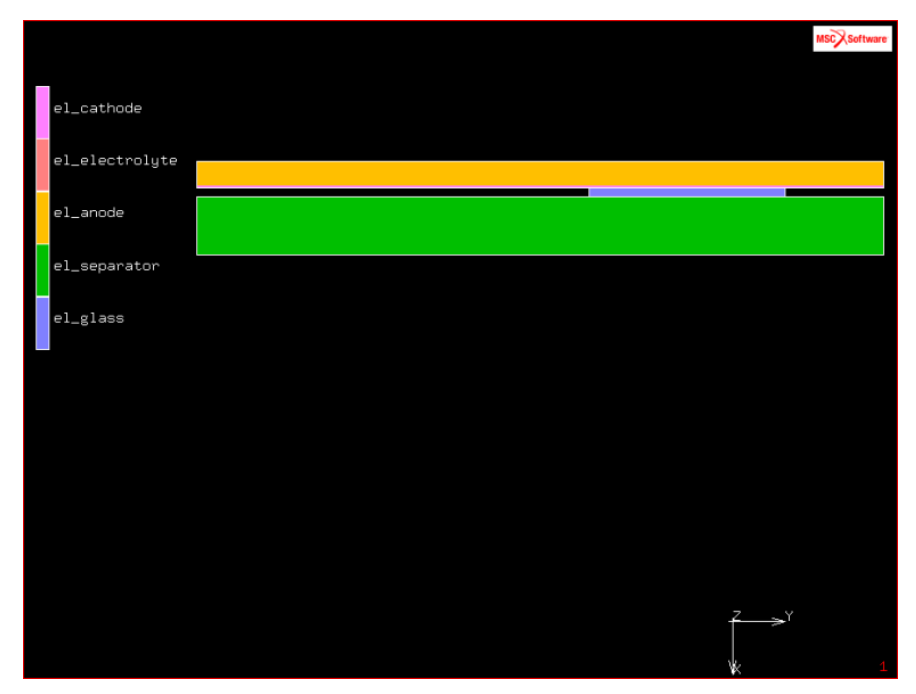

Figure 10 Schematic of model of setup without ceramic stoppers

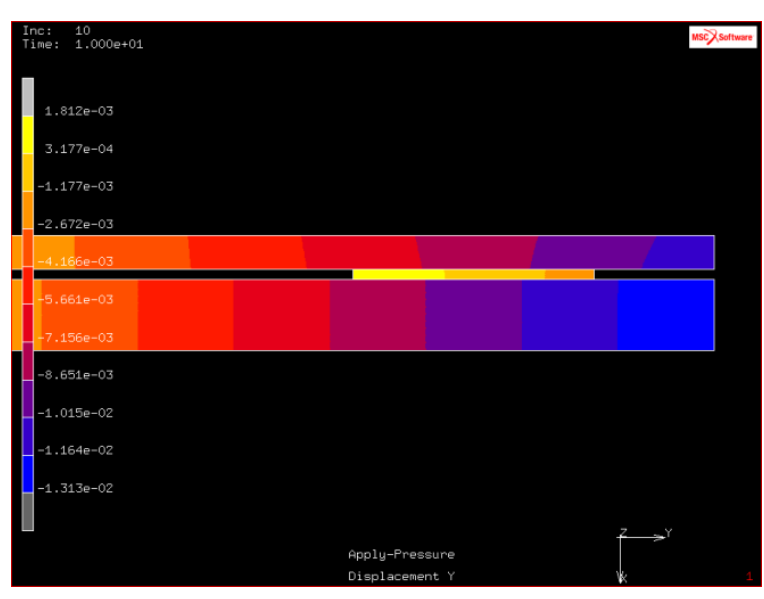

(a)

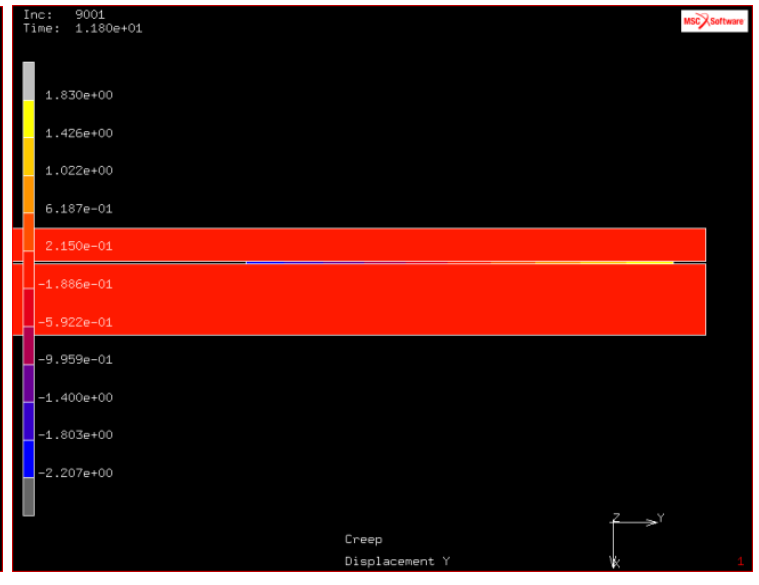

(b)

Figure 11 Deformed configurations (a) after applying top pressure; (b) creep in $2 \mathrm{~s}$ 


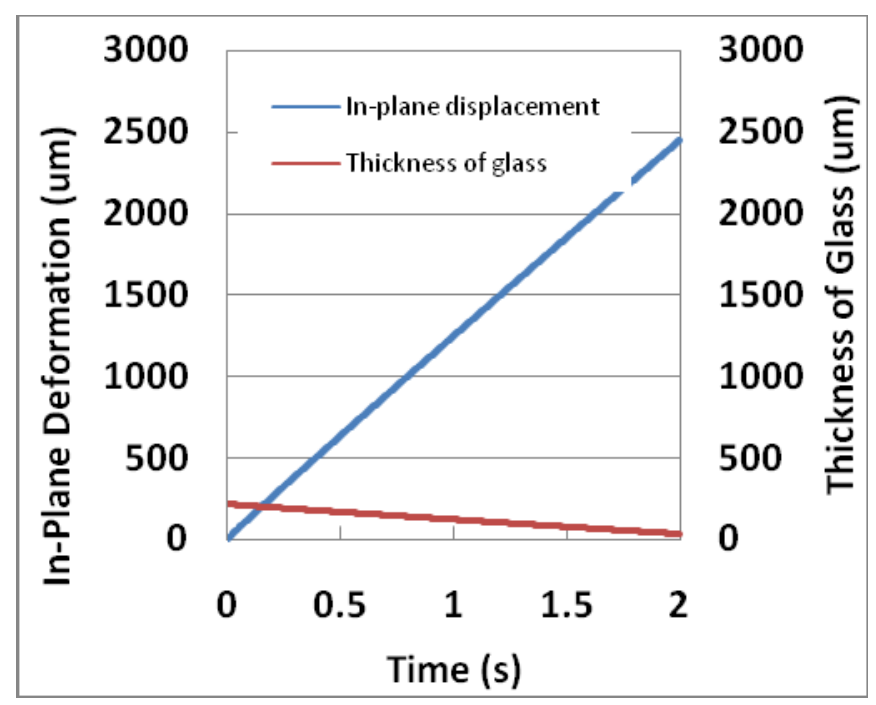

Figure 12 Deformation history of the inner side if the glass

Subsequently, we considered a nother case where the glass was not allowed to flow along the interfaces with PEN and IC. To co mpare the infl uence of the ceram ic stopper, the results with and without the ceramic stoppers are discussed here. Figure $13 \mathrm{~s}$ hows the deformed geometry of the glass without and w ith the st opper. Figure 13(a) shows the de formed configuration of glass seal after $36 \mathrm{~s}$ of creep for th e sealing system with $100 \%$ glas s seal and no ceram ic stopper. Figure 13(b) shows the deform ed configuration of the glass seal after 1000s of creep for the sealing system with $100 \%$ glas s seal but with ceram ic stopper. At the constrained points along the interfaces with PEN and IC, the glass material cannot move along the interfaces, however the glass at the middle part away from the inte rface will still flow out. The equivalent creep s train history at the middle point of the left edge (marked by arrow in Figure 13(a) and (b)) is depicted over time in Figure 14. It is obvious that without the ceramic stopper the strain at the middle part of the glass will con tinue to linearly increase. Such a lin ear strain versus time indicates that the $100 \%$ glass seal will continue to flow over time. W ith the ceram ic stopper, the creep deformation occurs only at the initial stage and then remains constant, because the shear stress in the glass will be relaxed out qui ckly and transferred into the ceramic stopper. Therefore, the geometry of the glass will be kept intact by the ceramic stopper. 


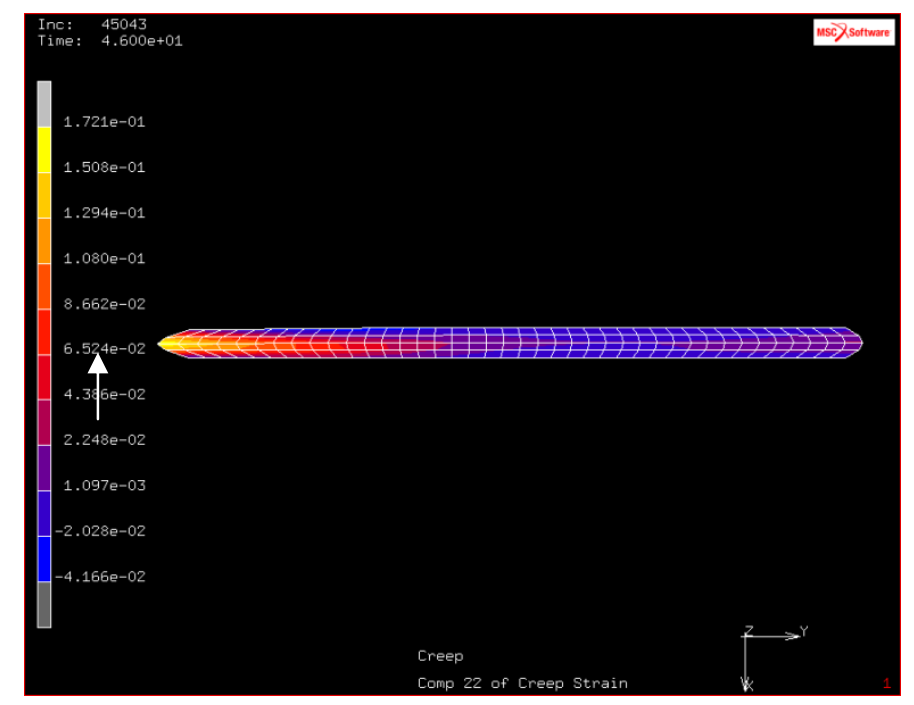

(a)

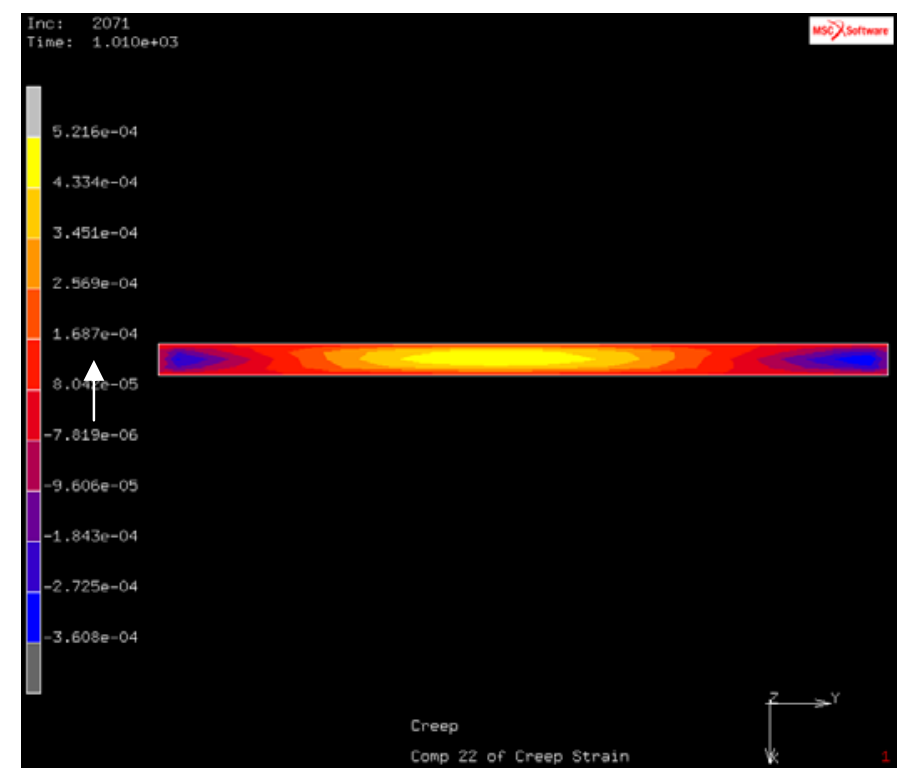

(b)

Figure 13 Deformed glass with distribution of equivalent creep strain after creep. (a) 36s of creep without stopper; (b) 1000s of creep with ceramic stopper 


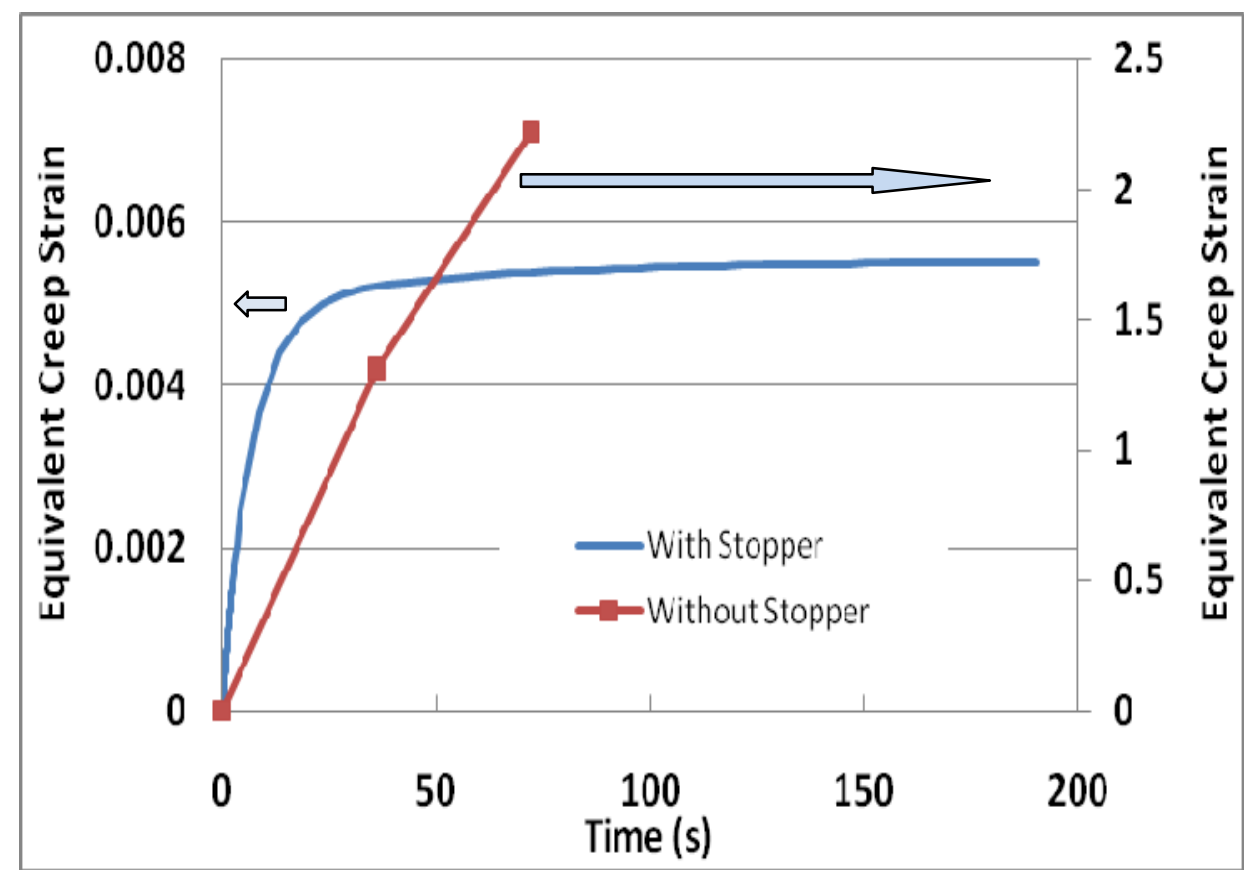

Figure 14 History of equivalent creep strain

\section{Stresses in the Glass Seal}

In order to prevent the glass seal out-flow, inner and outer ceramic stopper rings as those illustrated in Figures 2 and 3 are added to the next sealing system . Note that the glass seal an $d$ the ceramic stoppers are not bonded, and a sm all numerical gap of $0.063 \mathrm{mmm}$ is present in the model. Figure 15 and 16 show the distribution of maximum principal stress and shear stress in the glass seal at different stages of the sim ulation. Upon the initial te mperature drop from the stress-free temperature to the SOFC operating temperature, small magnitudes of thermal stresses are induced in the glass seal. These stres ses are relaxed out to even lower values during the first 3600 seconds of cell operation due to the creep behaviors of the glass seal. Upon cooling down to room temperature, relatively high thermal stress is predicted. These m odeling results indicate that the final cooling $\mathrm{s}$ tep to room tem perature is the $\mathrm{m}$ ost aggress ive one in term $\mathrm{s}$ of creating high stresses in the glass seal, and is $\mathrm{m}$ ost likely to create som e degree of da mage in the glass seal. The exact degree of da mage would depe nd on the room temperature bulk strength of the glass s eal. However, if the gl ass seal is truly self-healing, then th e cracks/damages will b e 
closed/healed up upon $\mathrm{r}$ eheating to the stack opera ting temperature, and the whole process will repeat itself in Figure 15 and 16 during the next thermal cycle.

For the next sealing system design, we exa mine the case where the ceramic stopper and the glass seal are fully bonded. Figure 17 and 18 illustrate the modeling results of the maximum principal stress and shear stress in the glass seal at different time steps, respectively. The trend in the stress history in th e seal is sim ilar to those presented earlier with a gap. However, in this case, the magnitudes of the tensile and shear stress upon cooling to room te mperature are $\mathrm{m}$ uch higher than those predicted earlier for the unbounded case with a small gap. These results indicate that leaving a $\mathrm{s}$ mall physical gap between the glass and ceram ic seal wi 11 help $\mathrm{m}$ itigate coolin $\mathrm{g}$ induced stress buildup in the seal, therefore reducing the degree of damage the glass seal $\mathrm{m}$ ay have upon cooling. A gain, if the glass seal is truly self-healing, the $\mathrm{m}$ agnitude of room temperature damage may not $m$ atter since all the cracks will be closed up and healed upon the next operating cycle.

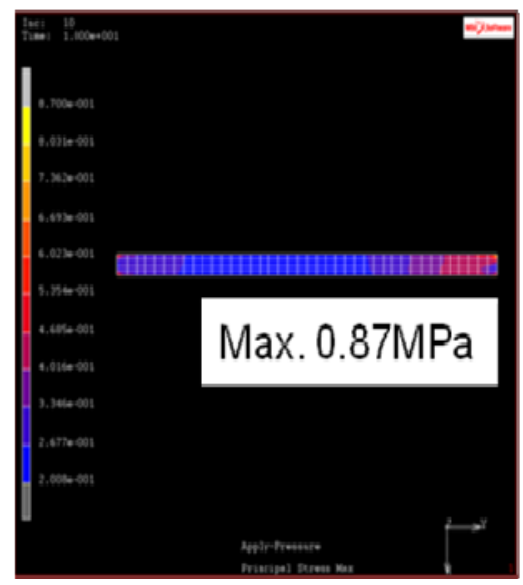

cooling to operating temperature

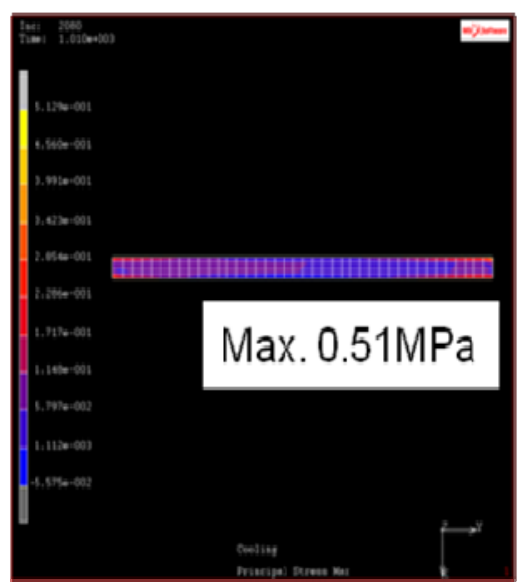

after 3600 seconds creep

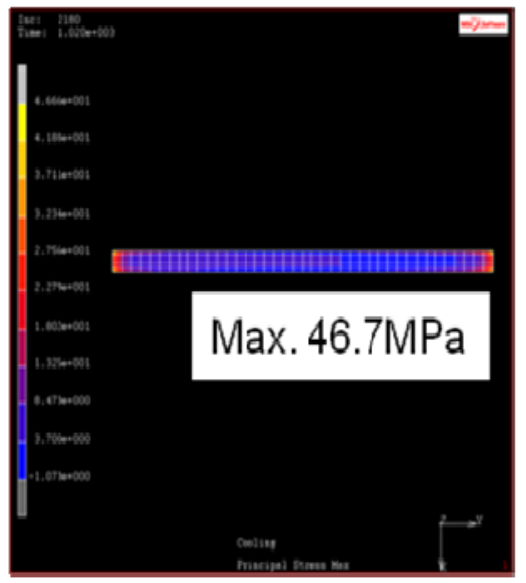

cooling to room temperature

Figure 15 Maximum principal stress contour of glass seal at the different time:weak interface between stopper and glass seal 


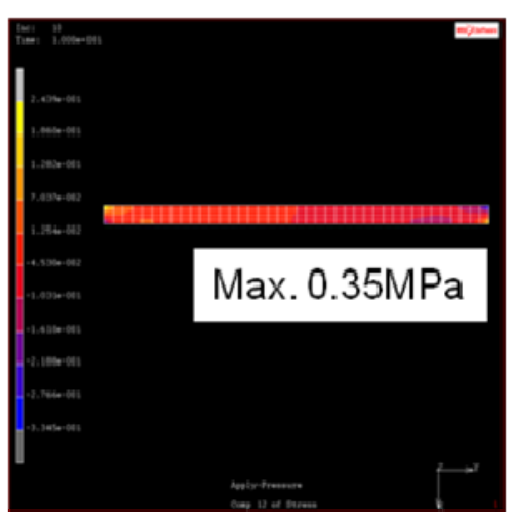

cooling to operating temperature

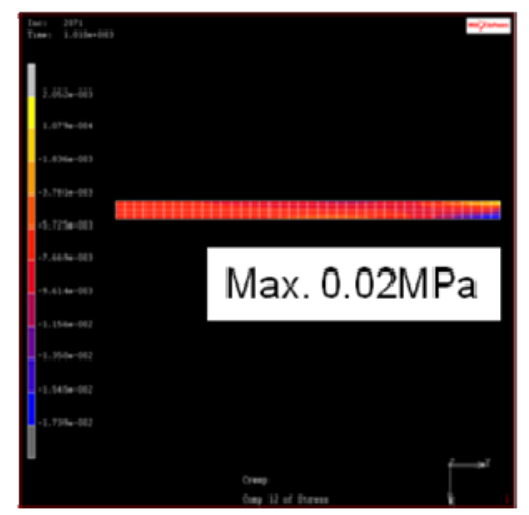

after 3600 seconds creep

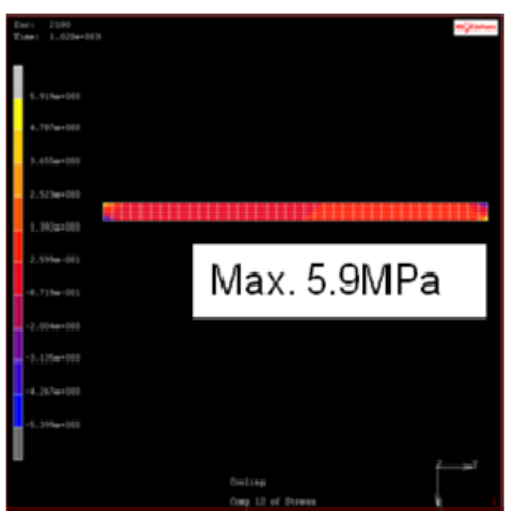

cooling to room temperature

Figure 16 Shear stress S12 contour of glass seal at the different time: weak interface between stopper and glass seal

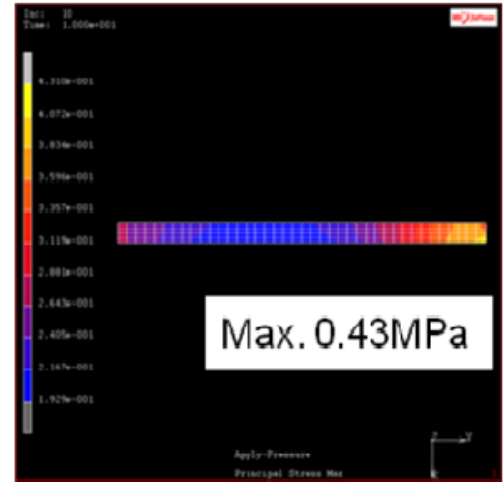

cooling to operating temperature

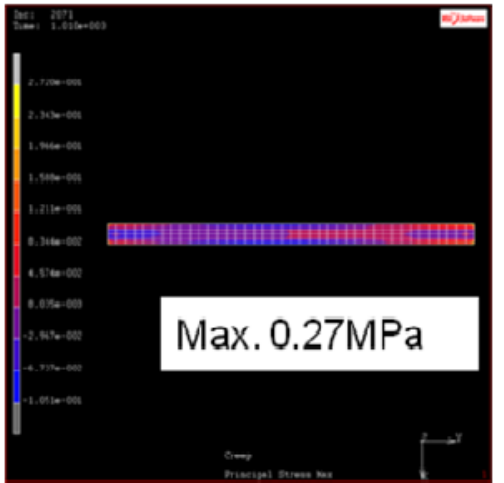

after 3600 seconds creep

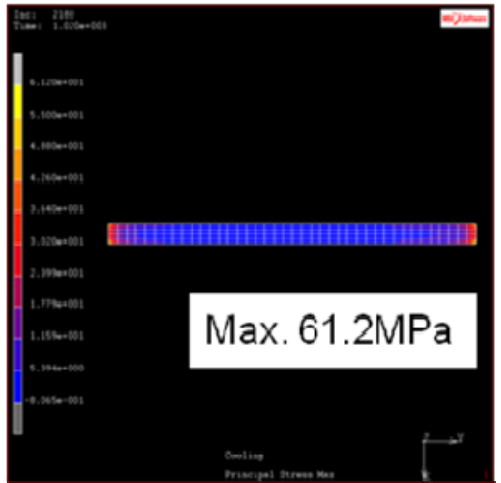

cooling to room temperature

Figure 17 Maximum pricipal stress contour of glass seal at the different: strong interface of stopper and glass seal 


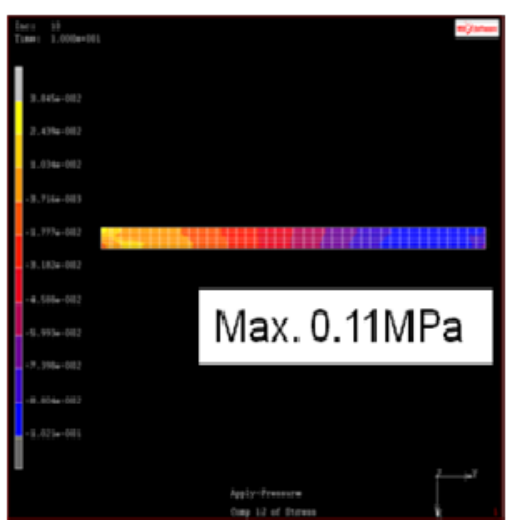

cooling to operating temperature

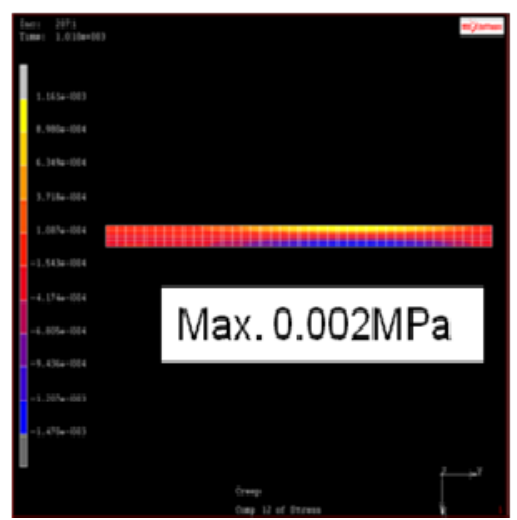

after 3600 seconds creep

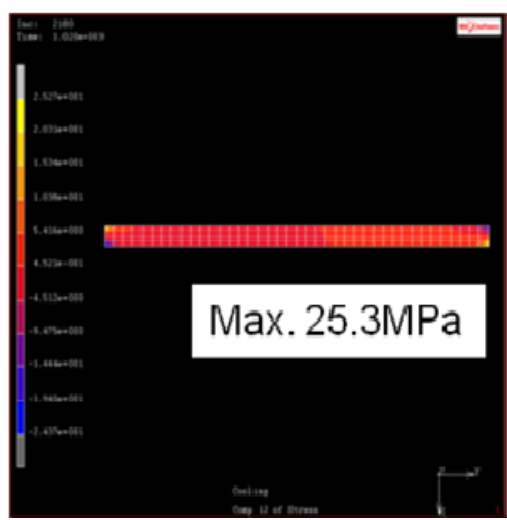

cooling to room temperature

Figure 18 Shear stress S12 contour of glass seal at the different time: strong interface of stopper and glass seal

Figures 19 and 20 depict the distribution of the shear stress and normal stress in the glass, respectively, during the cooling down process with a strong or weak stopper and glass interface. In Figure 19, with the weak stopper and glass interface, the stress in the glass is mainly related to the CTE mismatch between the glass, PEN, and IC. The temperature dependent CTE curves of glass and PEN intersect at the intermediate temperature of about $600 \mathrm{~K}$, i.e., the CTE of glass is higher than that of PEN at high temperatures, but lower than that of PEN at lower temperatures. With the strong stopper and glass interface, the stress in the glass, particularly near that interface, is influenced by the ceramic properties. After the cooling down process, the weak interface of the stopper and glass will create less interfacial shear stress and similar normal tensile stress. Whether the interface of the ceramic stopper and glass is strong or not, the highest stresses always occur at the edge of glass. In Figure 19 and 20, both of the maximum and minimum values of the stresses are given. For shear stresses, the positive and negative signs represent the directions of the shear stress, therefore only their magnitude has physical significance. For normal stresses, however, a positive value represents tensile normal stress on the interface, while a negative value represents compressive normal stress. Only a tensile normal stress on the interface will promote opening of the interface, i.e., interface delamination. 


\begin{tabular}{|c|c|c|c|c|c|}
\hline $\mathrm{T}(\mathrm{K})$ & \multicolumn{2}{|c|}{ Weak interface } & \multicolumn{2}{|c|}{ Strong interface } & $\mathrm{T}(\mathrm{K})$ \\
\hline \multirow[t]{2}{*}{834} & E & & E & & 829 \\
\hline & $6.7 \mathrm{MPa}$ & $-8.5 \mathrm{MPa}$ & $2.7 \mathrm{MPa}$ & $-4 \mathrm{MPa}$ & \\
\hline \multirow[t]{2}{*}{524} & $E$ & $\square$ & 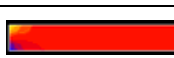 & & 519 \\
\hline & $16 \mathrm{MPa}$ & $-19 \mathrm{MPa}$ & $12 \mathrm{MPa}$ & $-14 \mathrm{MPa}$ & \\
\hline \multirow[t]{2}{*}{298} & & & & & 298 \\
\hline & $5.9 \mathrm{MPa}$ & $-5.4 \mathrm{MPa}$ & $25 \mathrm{MPa}$ & $-24 \mathrm{MPa}$ & \\
\hline
\end{tabular}

Figure 19 Shear stress distribution during the shutdown process with strong and weak interfaces of stopper and glass seal

\begin{tabular}{|c|c|c|c|c|c|}
\hline $\mathrm{T}(\mathrm{K})$ & \multicolumn{2}{|c|}{ Weak interface } & \multicolumn{2}{|c|}{ Strong interface } & $\mathrm{T}(\mathrm{K})$ \\
\hline \multirow{2}{*}{834} & [ & & ⿷ & $\square$ & 829 \\
\hline & $6.7 \mathrm{MPa}$ & $-8.5 \mathrm{MPa}$ & $2.7 \mathrm{MPa}$ & $-4 \mathrm{MPa}$ & \\
\hline \multirow[t]{2}{*}{524} & & & E & $\square$ & 519 \\
\hline & $16 \mathrm{MPa}$ & $-19 \mathrm{MPa}$ & $12 \mathrm{MPa}$ & $-14 \mathrm{MPa}$ & \\
\hline \multirow[t]{2}{*}{298} & $\square$ & & $\square$ & $\square$ & 298 \\
\hline & $5.9 \mathrm{MPa}$ & $-5.4 \mathrm{MPa}$ & $25 \mathrm{MPa}$ & $-24 \mathrm{MPa}$ & \\
\hline
\end{tabular}

Figure 20 Normal stress distribution during the shutdown process with strong and weak interface of stopper and glass

\section{Effect of Interfacial Conditions of Stopper with Other Components}

When applying ceramic stoppers to prevent the out-flow of the glass, the interfacial properties of the ceramic stopper with other components such as PEN, IC, and glass are closely dependent on the ceramic material and processing parameters. To evaluate the effect of the interfacial behaviors of the ceramic stopper with PEN and IC plate on the structure stability of the cell, two 
extreme cases - bonded and sliding, are considered here for bounding purpose. For any boundary conditions of stopper with PEN and IC, two types of interface between the stopper and glass are always considered here: bonded and unbonded.

Figures $21-26$ show the normal and shear stresses distribution on the interfaces of glass with PEN and IC, respectively, over the distance which starts from the innermost ends of the interfaces. Regardless of the interface properties between the ceramic stopper and PEN/IC, the weak interface between the stopper and glass will always create lower interfacial shear stress on both the glass/PEN and the glass/IC interfaces. The effect of the interfacial condition of the stopper and glass on the interfacial normal stress is less than that on the interfacial shear stress. In any case, high interfacial shear stress and normal stress are predicted in the vicinity of the two edges of the glass seal. The maximum normal stress on the interface is always higher than the maximum shear stress on the interface. The high interfacial normal stresses at the edge of the glass may lead to localized failure of the glass seal at the edge after cooling down to room temperature. It may also be seen that the normal stresses on the interfaces of glass with PEN and IC remain compressive in the middle portion of the glass seal, therefore the structure integrity of the glass seals will be maintained even if some localized edge failures occur during cooling.

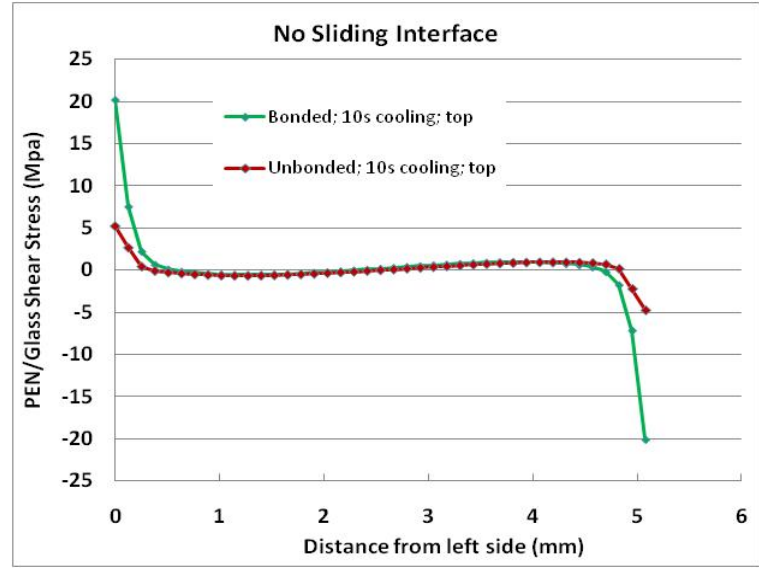

(a)

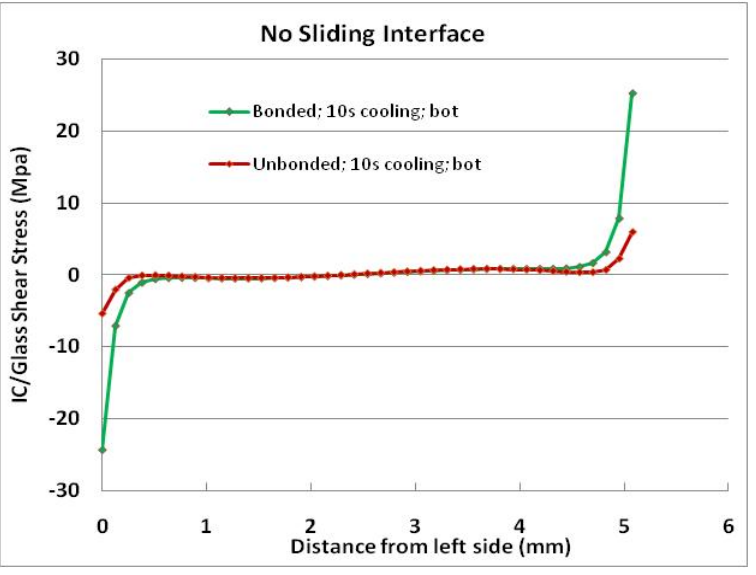

(b)

Figure 21 No sliding interface of stopper with PEN and IC: interfacial shear stress of glass (a) with PEN; (b) with IC 


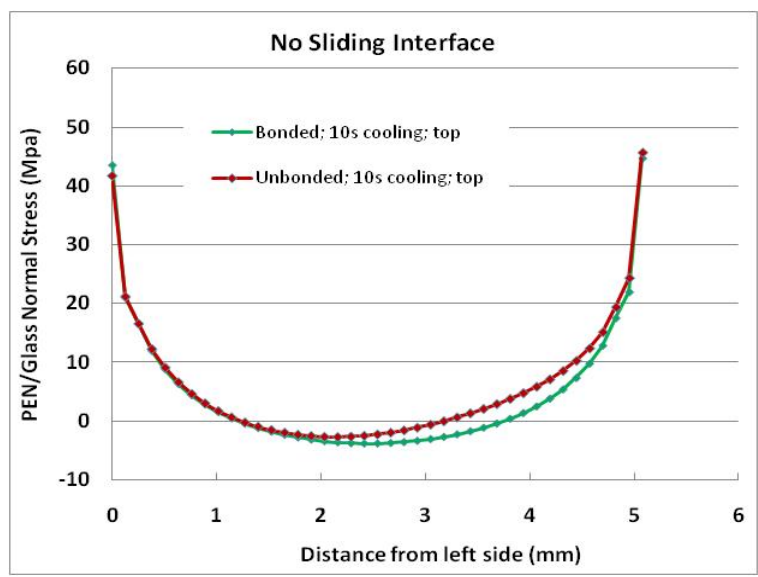

(a)

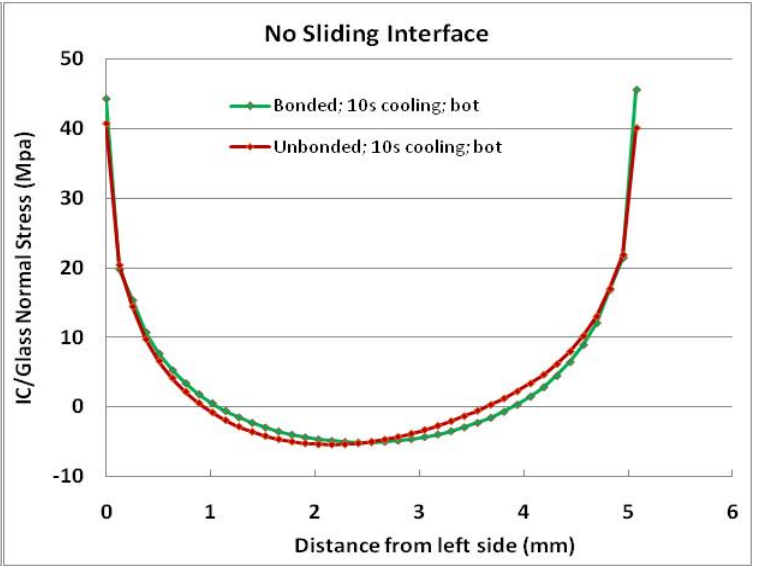

(b)

Figure 22 No sliding interface of stopper with PEN and IC: interfacial normal stress of glass with (a) PEN; (b) IC



(a)

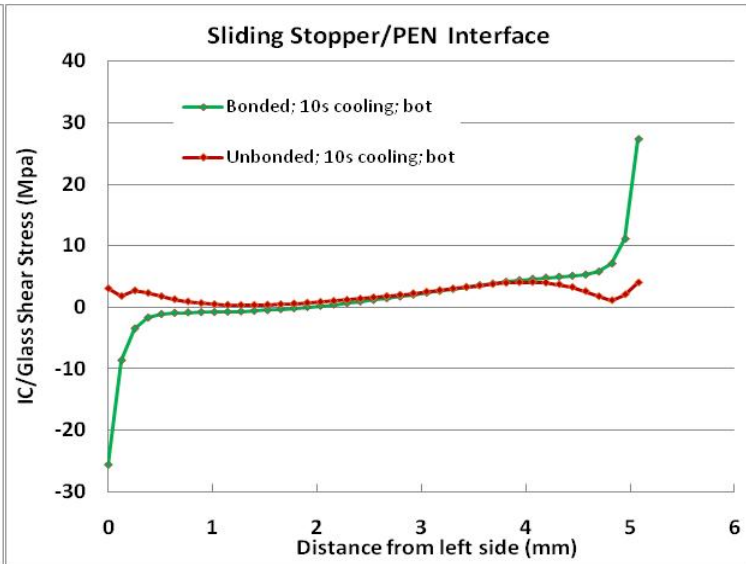

(b)

Figure 23 Sliding interface of stopper with PEN: interfacial shear stress of glass with (a) PEN; (b) IC 


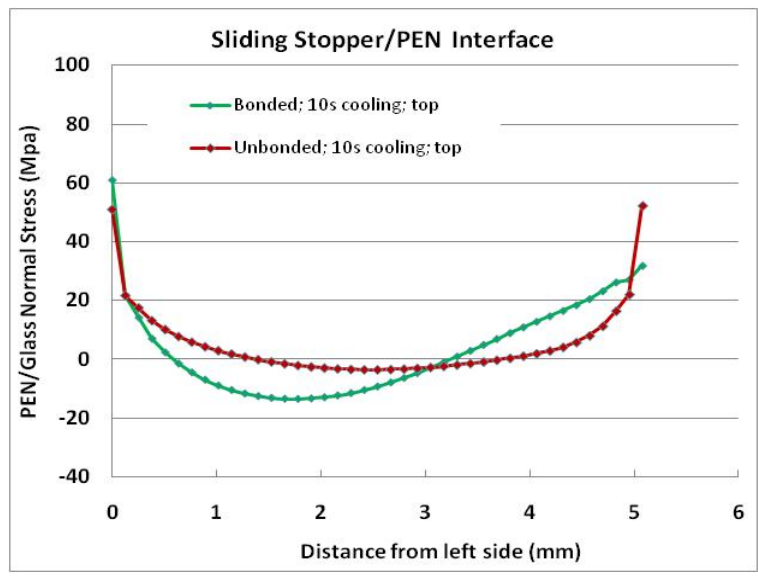

(a)

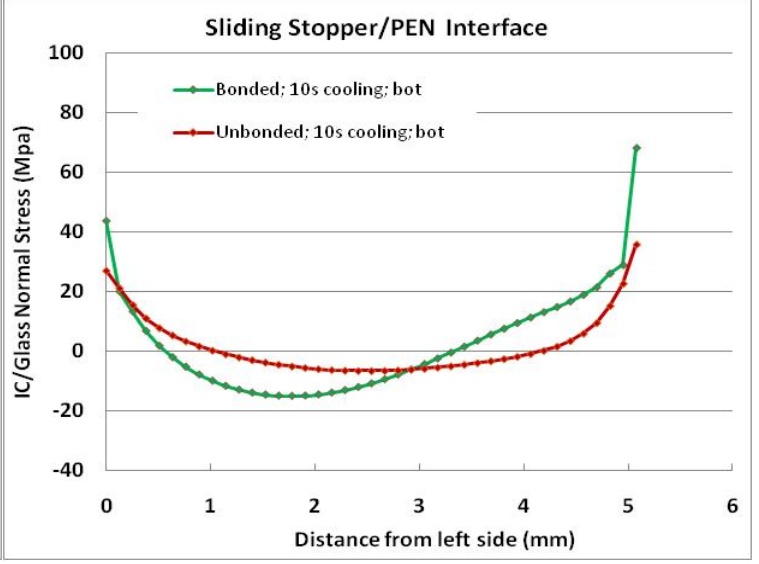

(b)

Figure 24 Sliding interface of stopper with PEN: interfacial normal stress of glass with (a) PEN;

(b) IC

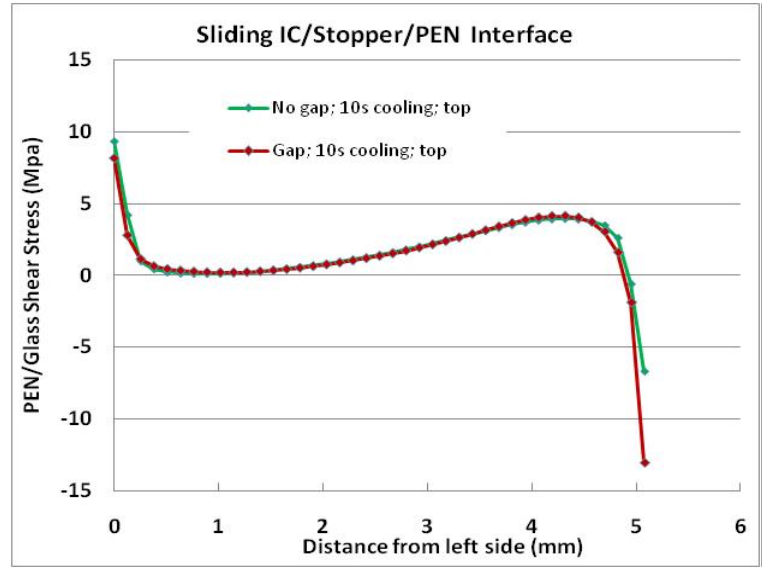

(a)

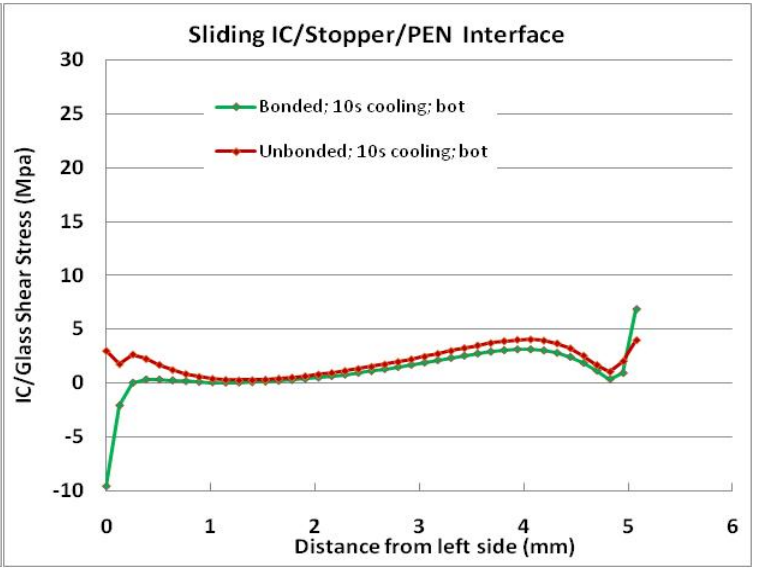

(b)

Figure 25 Sliding interfaces of stopper with PEN and IC: interfacial shear stress of glass with (a) PEN; (b) IC 


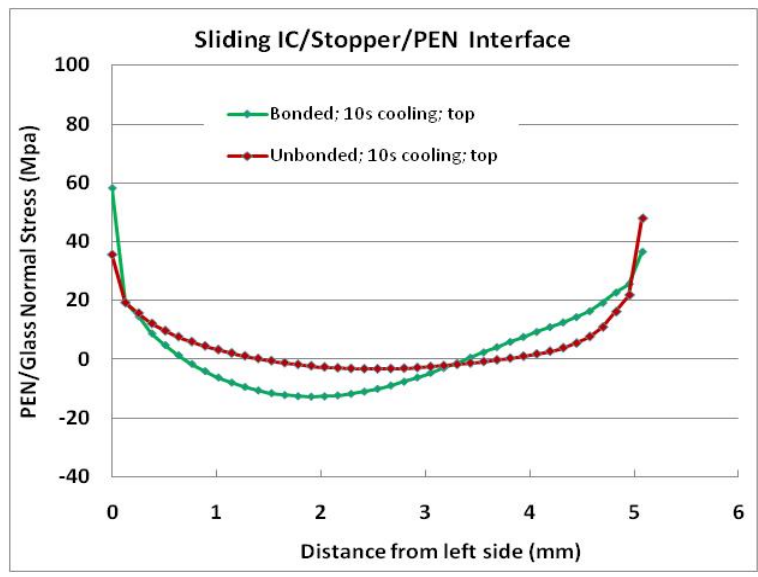

(a)

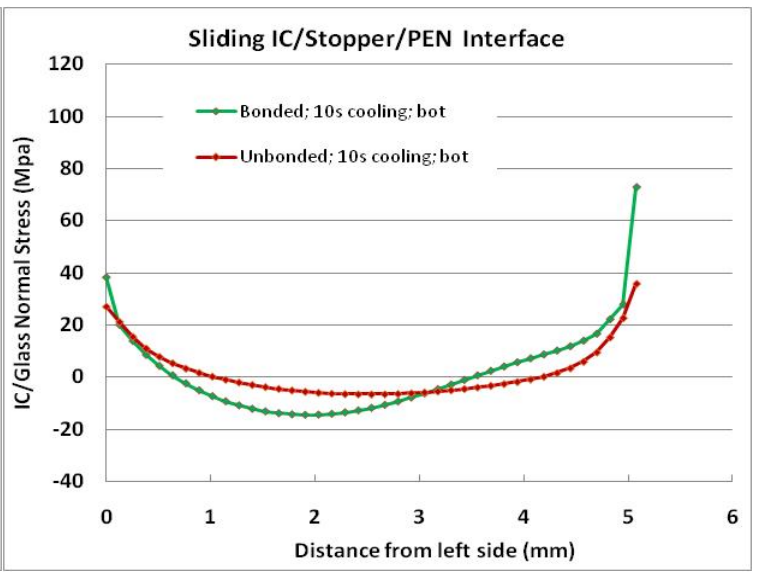

(b)

Figure 26 Sliding interfaces of stopper with PEN and IC: interfacial normal stress of glass with (a) PEN; (b) IC

\subsection{Conclusions}

In this repo rt, the geo metry stability of the self-healing glass and th e influence of various interfacial conditions of ceram ic stoppers with the PEN, IC , and glass seal on the structural integrity of the glass seal during the operati ng and cooling down processes are studied using finite element analyses. Two in terfacial conditions of the ceram ic stopper and glass seals, i.e., bonded (strong) or un-b onded (weak), are consider ed. The interfacial co nditions of the ceram ic stopper with the PEN and IC plates are assumed to be bonded or sliding.

Based on the analyses results, the following observations and conclusions can be made:

(1) Self-healing glass alone cannot sustain its geometry in a sealing system for SOFC. The glass seal material will flow out quickly due to its low viscosity at high SOFC operating temperature.

(2) Ceramic stoppers are necessary and helpful in maintaining the geometrical stability of the self-healing glass in a sealing system for SOFCs. 
(3) Under the operating environment of SOFCs, the stress level in the glass seal is very low. The initial stresses induced by the temperature drop from the stress-free assembly temperature to working temperature of SOFCs are relaxed quickly during the operation of SOFCs.

(4) After the cooling down process, the CTE mismatch will result in relatively high stress in glass materials and on the interfaces of the glass seal with other components. It should be noted that the high stress occurs only locally at the edges of the glass seal, which may cause localized failure of the glass interfaces.

(5) Despite the localized tensile normal stress at the interface between the glass seal with the PEN and IC, the compressive normal stresses in the middle portion of the glass seal will maintain the structure integrity of the glass seal system.

Our future work includes the examination of possible volume changes of the glass during the sintering process and its influence on the structural integrity of the sealing system in SOFCs. Effects of the applied glass paste volume, ceramic stoppers geometry, as well as the thermalmechanical properties of glass on the geometry stability and structural integrity of the glass seal system will be studied. Further work in these areas is currently underway. 


\subsection{References}

1. W.N. Liu, X. Sun, B. Koeppel, M. Khaleel, Experimental study of the aging and selfhealing of the glass/ceramic sealant used in SOFCs, International Journal of Applied Ceramic Technology, v 7, n 1, p 22-29, January-February 2010

2. R. N. Singh, Sealing Technology for Solid Oxide Fuel Cells (SOFC), International Journal of Applied Ceramic Technology, 4 (2), pp. 134-144 (2007)

3. Edgar Lara-Curzio, et al., Characterization of SCN-1 Glass.

4. E. L. Bourhis, P. Gadaud, J. P. Guin, N. T ournerie, X. H. Zhang, J. Lucas, T. Rouxel, Scripta Materilia 45, 2001, pp. $317-323$.

5. J. P. Andrews, Proc. Phys. Soc., 36, 1924, pp. $169-177$.

6. N. Govindaraju, et at, Journal of Power Sources, v 190, n 2, p 476-84, 15 May 2009

7. Rosa M. Trejo, et al, SCNP-TMA.xls, Mar. 2010.

8. Rosa M. Trejo, et al, Viscosity and Wetting Behavior of SCN-1 Glass, Nov. 2009. 